\title{
Permanent His bundle pacing and atrioventricular node ablation for rate control in permanent atrial fibrillation. A case report
}

\author{
Catalin Pestrea ${ }^{1,2}$, Alexandra Gherghina', Irina Pintilie², Florin Ortan ${ }^{2}$
}

\begin{abstract}
Atrial fibrillation (AF) is a serious cause of morbidity and mortality in the general population, with an increasing prevalence with the improvement in diagnosis. The best current treatment approach is catheter ablation (mainly isolation of the pulmonary veins), but this is ineffective in permanent atrial fibrillation. Rate control is frequently mandatory in these patients and the most effective technique is atrioventricular node ablation. But, since this procedure renders the patient pacemaker dependent, one should be very cautious with the pacing mode selected for long-term pacing. We present the case of a 45 year-old male with permanent atrial fibrillation and drug-refractory rapid ventricular rate and tachycardia-induced cardiomyopathy, who underwent catheter ablation of the atrioventricular node and permanent selective His bundle pacing. Following the procedure, the patient went from a rapid, irregular rhythm to a controlled, regular rhythm without a change in QRS morphology. The follow-up after three months showed near complete recovery of the left ventricle and the disappearance of heart failure symptoms.
\end{abstract}

Keywords: His bundle pacing, AV node ablation, atrial fibrillation.

Rezumat: Fibrilația atrială reprezintă o cauză semnificativă de morbiditate și mortalitate în populația generală, cu o prevalență în creștere odată cu ameliorarea metodelor de diagnostic. Cea mai bună opțiune terapeutică în acest moment este ablația pe cateter (în principal izolarea venelor pulmonare), dar aceasta este ineficientă în fibrilația atrială permanentă. Controlul frecvenței este frecvent necesar la acești pacienți și cel mai eficient mod prin care se poate obține este ablația nodului atrioventricular. Dar, din moment ce pacientul devine dependent de cardiostimularea artificială, o atenție deosebită trebuie acordată modului de stimulare ales pe termen lung. Prezentăm cazul clinic al unui bărbat în vârstă de 45 de ani, cu fibrilație atrială permanentă și frecvență ventriculară înaltă refractară la tratamentul bradicardizant, cu o cardiomiopatie indusă de tahicardie, care a fost tratat prin ablația nodului atrioventricular și stimularea permanentă selectivă a fasciculului His. Postprocedural, pacientul a trecut de la un ritm rapid și total neregulat, la un ritm controlat, regulat, fară nicio modificare a morfologiei complexului QRS. Controlul de trei luni a evidențiat recuperarea aproape completă a ventriculului stâng și dispariția simptomatologiei de insuficiență cardiacă.

Cuvinte cheie: stimularea fasciculului His, ablația nodului atrioventricular, fibrilație atrială.

\section{INTRODUCTION}

Atrial fibrillation (AF) is a serious cause of morbidity and mortality in the general population, with an increasing prevalence with the improvement in diagnosis. The best current treatment approach is catheter ablation (mainly isolation of the pulmonary veins), but this is ineffective in permanent atrial fibrillation. Rate control is frequently mandatory in these patients and the most effective technique is atrioventricular node ablation. But, since this procedure renders the patient

\footnotetext{
' Unit of Intensive Cardiac Care, County Emergency Clinical Hospital, Brasov, Romania

${ }^{2}$ Unit of Interventional Cardiology, County Emergency Clinical Hospital,

Brasov, Romania
}

pacemaker dependent, one should be very cautious with the pacing mode selected for long-term pacing.

\section{CASE REPORT}

A 45 year old male patient was admitted to our hospital for progressively severe shortness of breath and exercise intolerance, spanning over the last 6 months. His medical history included obesity and type 2 diabetes mellitus and a diagnosis of atrial fibrillation made approximately 4 years ago.

\footnotetext{
$\checkmark$ Contact address:

Catalin Pestrea, Unit of Intensive Cardiac Care, County Emergency Clinical Hospital, 25-27Calea Bucuresti, Brasov, Romania.

E-mail: pestrea.catalin@gmail.com
} 


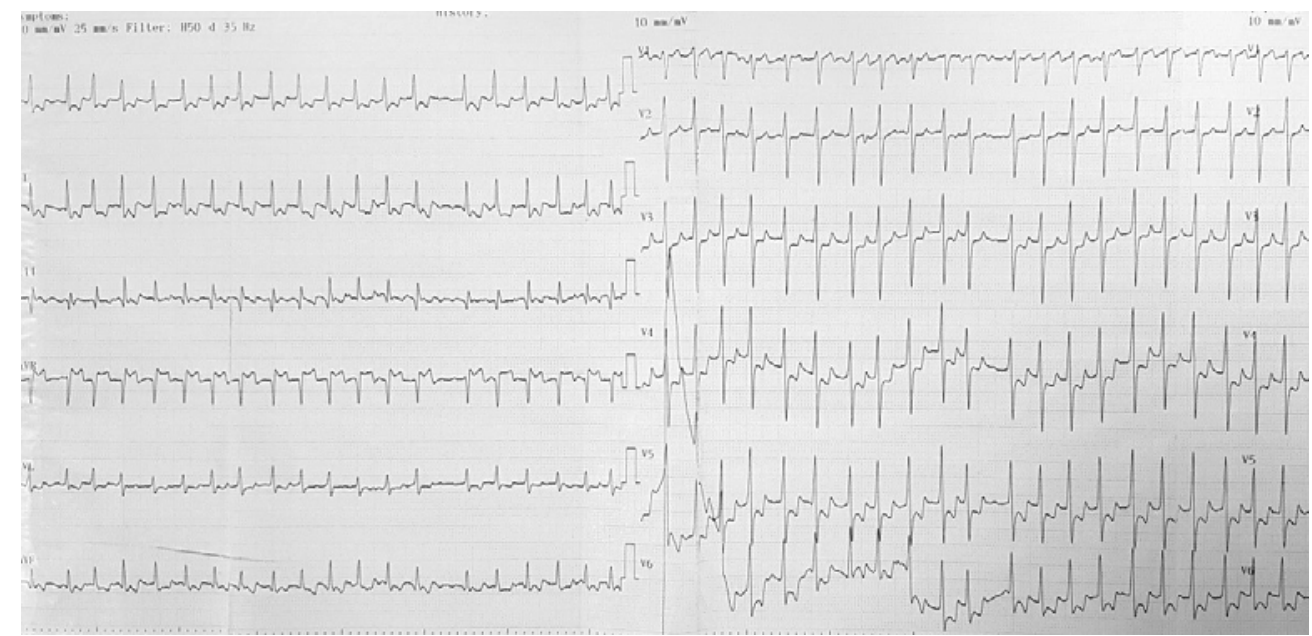

Figure I. Pre-procedural ECG showing atrial fibrillation with rapid ventricular conduction.

The presenting ECG showed atrial fibrillation with a rapid ventricular rate of I $30-140 \mathrm{bpm}$ (Figure I). The blood tests showed hyperglycemia and dyslipidemia with normal myocardial markers.

The echocardiogram showed an enlarged left atrium, a dilated left ventricle with a severely depressed ejection fraction and a moderate to severe mitral regurgitation (Figure 2). A coronary angiography was performed which excluded coronary artery disease.

Since the exact pattern of atrial fibrillation was unknown and there was never an attempt to restore sinus rhythm, a transesophageal echocardiogram was performed, which revealed the presence of thrombus in the left atrial appendage, therefore contraindicating the electrical cardioversion. The patient was discharged on oral anticoagulants (Apixaban $5 \mathrm{mg}$ b.i.d.), Metoprolole succinate $200 \mathrm{mg}$ daily and Digoxin $0.25 \mathrm{mg}$ daily for rate control.

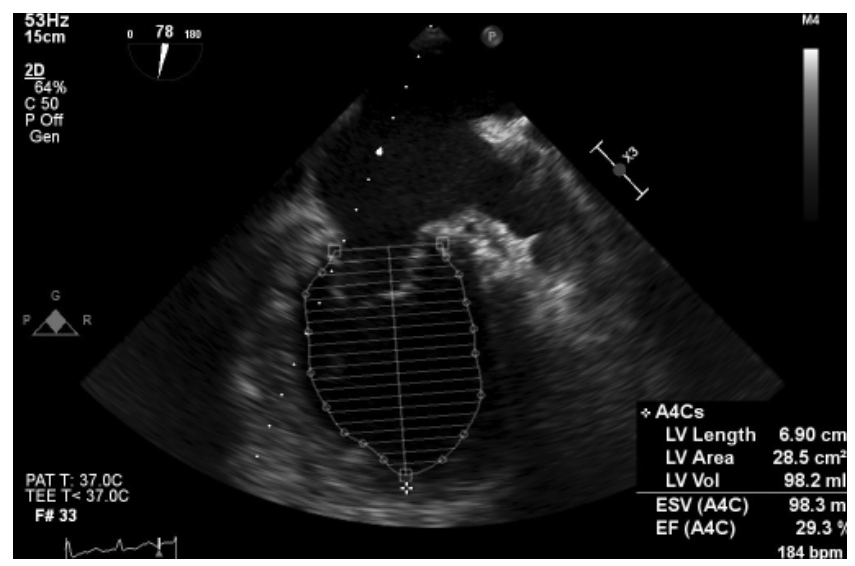

Figure 2. Transesophageal image showing dilated left ventricle with severely depressed ejection fraction.
Two months later, the patient was readmitted with worsening symptoms. The ECG showed again atrial fibrillation with high ventricular rate despite full compliance to the atrioventricular node blocking agents. The repeat transesophageal echocardiography showed the disappearance of the left atrial appendage thrombus. In this case, an electrical cardioversion was attempted. Despite the use of maximal energy of the biphasic shock and with different vector orientations, the attempts to restore sinus rhythm were unsuccessful.

Therefore, given the echocardiographic aspect, we established the diagnosis of permanent atrial fibrillation with a probable tachycardia-induced cardiomyopathy, with a failure to control the heart rate, even with a combination of atrioventricular (AV) node blocking agents. Because of the severity of symptoms, we presented the patient with an ablate and pace strategy. In order to avoid inducing dyssynchrony with pacing the myocardium, we opted for the most physiological form of conduction system pacing, namely His bundle pacing.

Using the current available preformed delivery sheath (C3I5 His - Medtronic, Minneapolis), a 3830 Select Secure lead (Medtronic, Minneapolis) was used to map a His bundle signal as distally as possible (Figure 3), with a selective pacing response (the paced QRS complex was identical to the native one) at a low threshold value (IV at I msec), and at that place the lead was screwed in. Next, a $4 \mathrm{~mm}$ ablation catheter was placed via the left femoral vein in the region of the $A V$ node, which was approximately $\mathrm{I} \mathrm{cm}$ posterior and inferior to the lead tip (Figure 4) and radiofrequency was applied until ablation of the AV node was noted with a junctional escape rhythm of $40 \mathrm{bpm}$. The pacing 


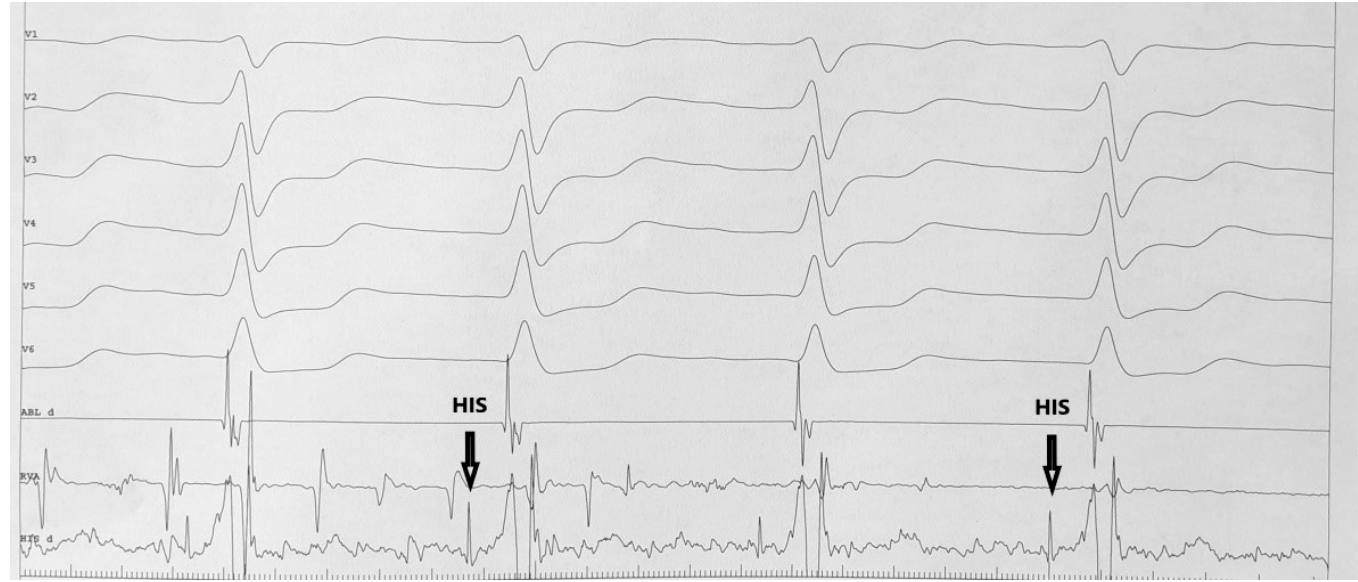

Figure 3. His bundle signal during mapping of the atrioventricular junction with the pacing lead.

lead was afterwards connected to a VVIR pacemaker that was set at a rate of $80 \mathrm{bpm}$.

The post-procedural ECG showed a regular paced rhythm with a narrow QRS complex identical to the native one (Figure 5). The patient was discharged the next day on optimal medical treatment for heart failure including metoprolole succinate $200 \mathrm{mg}$ daily, ramipril $5 \mathrm{mg}$ daily and spironolactone $25 \mathrm{mg}$ daily.

The three months device follow-up showed nearly $100 \%$ pacing burden with stable pacing and sensing thresholds (IV/I ms and $5 \mathrm{mV}$, respectively). The control echocardiography showed significant recovery of the systolic function with an ejection fraction of 50 $\%$, a reduction in both end-diastolic and end-systolic volumes and a reduction in mitral regurgitation from moderate-severe to mild (Figure 6).

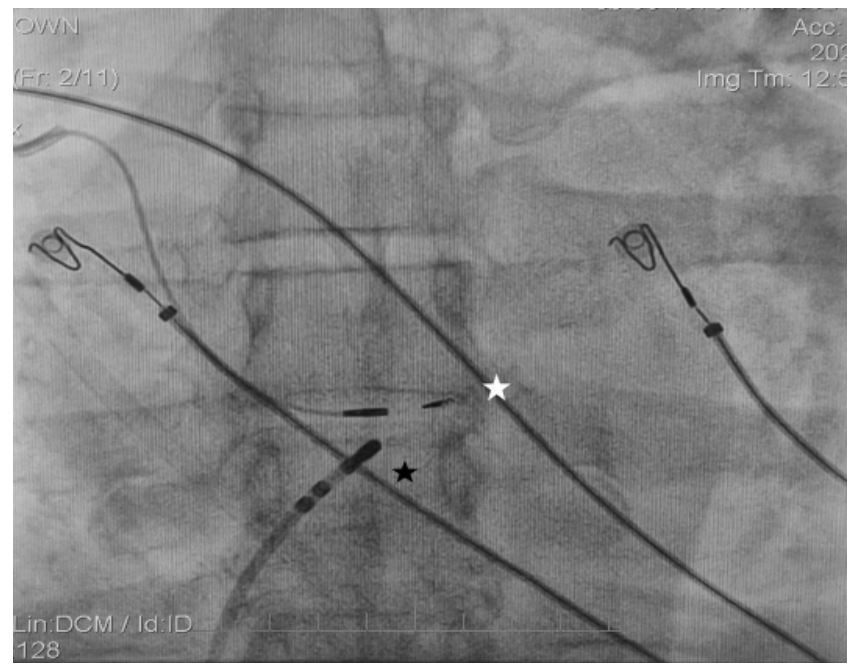

Figure 4. Fluoroscopic image of the His bundle pacing lead (white star) and the ablation catheter (black star).

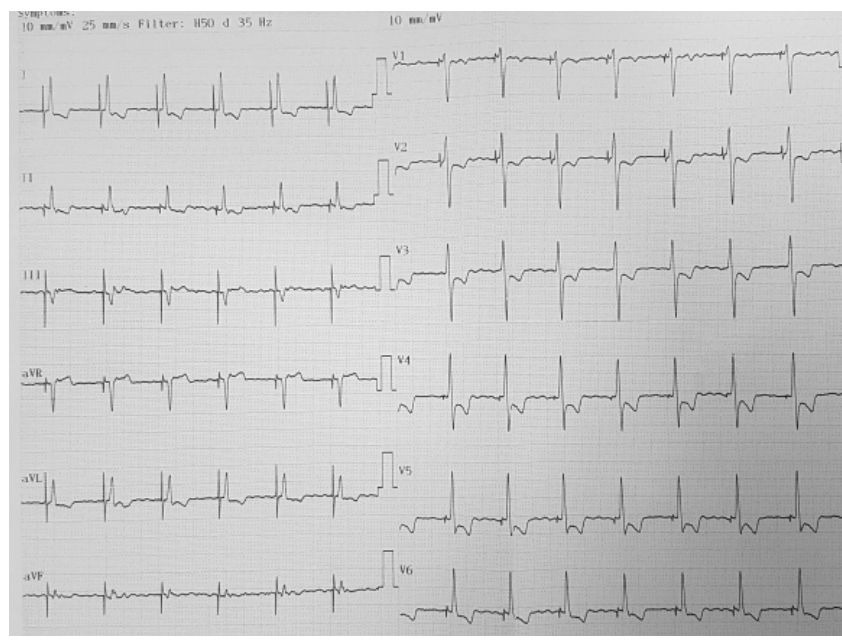

Figure 5. Post-procedural ECG showing a regular, paced rhythm with an identical QRS complex as to the native one (selective His bundle pacing).

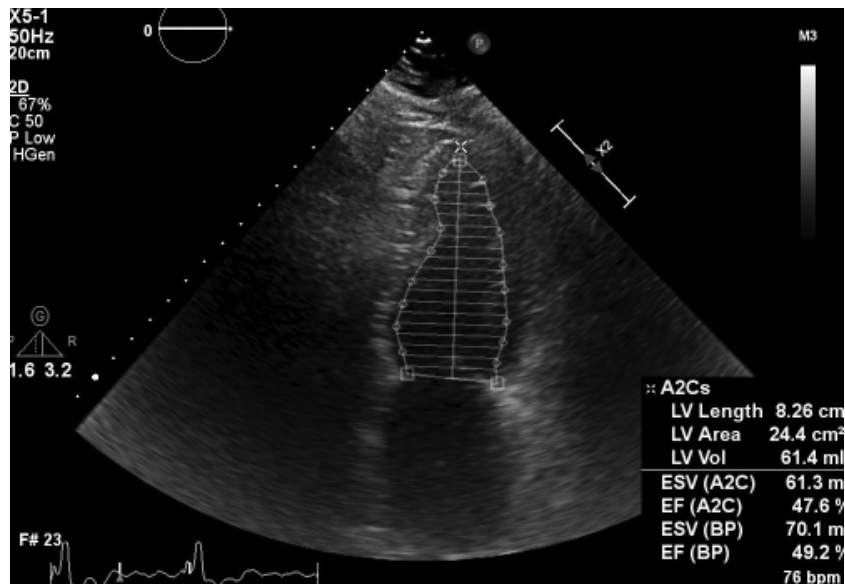

Figure 6. Transthoracic echocardiography image showing significantly improved left ventricle dimensions and ejection fraction. 


\section{DISCUSSION}

Atrial fibrillation is the most common arrhythmia in general population, with an increasing incidence with older age. It is associated with significant morbidity and mortality, which is the reason for the growing interest in treating this pathology in the last decades'. Recent advances in ablation technology have made a major breakthrough in restoring sinus rhythm in patients with paroxysmal and even persistent forms of atrial fibrillation with success rates of up to $90 \%{ }^{2}$.

Unfortunately, catheter ablation is not an option for permanent AF. Usually, the cause of morbidity in these patients is the long-term combination of a totally irregular and fast heart rate, which frequently leads to increased left ventricular volumes and a decrease in ejection fraction, the so-called tachycardia-induced cardiomyopathy ${ }^{3}$. Therefore, rate control in these patients is the only option for improving symptoms and outcomes. Common drugs used for rate control are beta-blockers, calcium channel blockers and digoxin, alone or in combination. Unfortunately, especially in younger patients with normal AV nodal conduction, blocking the AV node is extremely difficult without the risk of adverse effects due to high medication doses. That is why, especially in patients with reduced ejection fraction, a more radical approach like AV node ablation can be used. This procedure is extremely effective in achieving rate control, but at the expense of rendering the patient pacemaker-dependent.

Pacing the right ventricle after $\mathrm{AV}$ node ablation can be deleterious in the long-term because the benefit of heart rate reduction and regularization could be offset by the pacing-induced dyssynchrony, which could lead to further systolic dysfunction ${ }^{4}$. That is why, until recently, biventricular pacing was recommended after AV node ablation in patients with reduced ejection fraction ${ }^{5}$. Nevertheless, biventricular pacing is not entirely physiological, and it was proven to still induce a degree of ventricular dyssynchrony, especially in patients with a baseline narrow QRS complex ${ }^{6}$.

For these reasons, in the last decades, more physiological pacing methods have been intensively studied. Out of these methods, His bundle pacing has emerged as the most physiological one, as it uses the intrinsic conduction system for ventricular depolarization ${ }^{7}$.

As a consequence, in our patient, we opted for a strategy of His bundle pacing after AV node ablation, because this combination provides the best outcomes from both procedures: a reduction and regularization of the heart rhythm, while completely maintaining the synchrony of ventricular activation.

In our patient we managed to achieve a selective response to His bundle pacing, which means that the paced QRS complex is identical to the native one ${ }^{8}$. Thus, the patient switches from an irregular and fast rhythm to a perfectly regular and well controlled rhythm, without a change in QRS morphology. In this situation, it is impossible not to have positive outcomes after the procedure.

There are, however, some particularities in ablating the AV node after His bundle pacing. If the ablation site is too close to the lead tip, a significant increase in pacing threshold could occur. Therefore, the lead tip should be as distally implanted in the His bundle as possible, and the ablation catheter should be placed as proximally as possible in the AV node, usually at the level of the proximal ring electrode, as we performed in our patient?.

There are several retrospective studies in the literature showing similar results as we observed in our patient, that is a significant improvement in symptomatology and an increase in systolic function.

The feasibility of His bundle pacing has been shown in thousands of patients with stable pacing and sensing thresholds in the long-term ${ }^{10}$. Our patient was not an exception with constant thresholds at the three months follow-up.

For all the reasons mentioned above, there is now a class Ila, level of evidence $C$ guideline recommendation in the 2019 ESC Guidelines on Supraventricular Tachycardia for His bundle pacing after AV node ablation for drug resistant atrial arrhythmias and tachycardia-induced cardiomyopathy" and a positive remark in the 2020 ESC Guidelines on Atrial Fibrillation, considering it a very attractive alternative pacing mode ${ }^{12}$. Of course, future randomized trials are certainly needed to establish this practice as a standard of care.

\section{CONCLUSION}

His bundle pacing and atrioventricular node ablation is probably the most efficient method for rate control in patients with permanent atrial fibrillation with a rapid heart rate and tachycardia-induced cardiomyopathy, as it leads to a reduction and regularization of the heart rate, while providing physiological biventricular electrical activation.

Conflict of interest: none declared. 


\section{References}

I. Johansson C, Dahlqvist E, Andersson J, Jansson JH, Johansson L. Incidence, type of atrial fibrillation and risk factors for stroke: a population-based cohort study. Clin Epidemiol. 2017;9:53-62. Published 2017 Jan 24. doi:I0.2147/CLEP.SI22916.

2. Taghji P, El Haddad M, Phlips T, Wolf M, Knecht S, Vandekerckhove $Y$, Tavernier R, Nakagawa H, Duytschaever M. Evaluation of a Strategy Aiming to Enclose the Pulmonary Veins With Contiguous and Optimized Radiofrequency Lesions in Paroxysmal Atrial Fibrillation: A Pilot Study. JACC Clin Electrophysiol. 2018 Jan;4(I):99-108. doi: 10.1016/j.jacep.2017.06.023. Epub 2017 Sep 27. PMID: 29600792.

3. Kim DY, Kim SH, Ryu KH. Tachycardia induced Cardiomyopathy. Korean Circ J. 2019;49(9):808-8I7. doi:I0.4070/kcj.2019.0199.

4. Khurshid Shaan, Epstein Andrew, Verdino Ralph, Lin David, Goldberg Lee, Marchlinski Francis, Frankel David. (2014). Incidence and Predictors of Right Ventricular Pacing-Induced Cardiomyopathy.. Heart rhythm: the official journal of the Heart Rhythm Society. I I. 10.1016/j.hrthm.2014.05.040.

5. Orlov MV, Gardin JM, Slawsky M, Bess RL, Cohen G, Bailey W, Plumb V, Flathmann H, de Metz K. Biventricular pacing improves cardiac function and prevents further left atrial remodelling in patients with symptomatic atrial fibrillation after atrioventricular node ablation. Am Heart J 20 10; 159:264-270.

6. Gauthey, A., Willemen, E., Lumens, J., Ploux, S., Bordachar, P., Ritter, P., Waroux, J. le P. (2020). Impact of Paced Left Ventricular Dyssynchrony on Left Ventricular Reverse Remodeling after Cardiac Resynchronization Therapy. Journal of Cardiovascular Electrophysiology. doi: I0. I I I I/jce. I4330.

7. Keene $D$, Arnold AD, Jastrzębski M,et al. His bundle pacing, learning curve, procedure characteristics, safety and feasibility: insights from a large international observational study. J Cardiovasc Electrophysiol.2019;30:1984-1993.

8. Vijayaraman P, Dandamudi G, Zanon F, Sharma PS, Tung R, Huang W, Koneru J, Tada H, Ellenbogen KA, Lustgarten DL. Permanent His bundle pacing: Recommendations from a Multicenter His Bundle Pacing Collaborative Working Group for standardization of definitions, implant measurements, and follow-up. Heart Rhythm. 2018 Mar;I5(3):460-468. doi: 10.1016/j.hrthm.2017.10.039. Epub 2017 Oct 28. PMID: 29107697.

9. Vijayaraman P, Subzposh FA, Naperkowski A. Atrioventricular node ablation and His bundle pacing. Europace. 2017 Dec I; I9(suppl_4): iv 10-iv 16. doi: 10.1093/europace/eux263. PMID: 29220422.

10. Huang W, Su L, Wu S, Xu L, Xiao F, Zhou X, Ellenbogen KA. Benefits of Permanent His Bundle Pacing Combined With Atrioventricular Node Ablation in Atrial Fibrillation Patients With Heart Failure With Both Preserved and Reduced Left Ventricular Ejection Fraction. J Am Heart Assoc. 2017 Apr 1;6(4):e005309. doi: 10.1161/ JAHA. I 16.005309. PMID: 28365568; PMCID: PMC5533020.

II. Josep Brugada, Demosthenes G Katritsis, Elena Arbelo, Fernando Arribas, Jeroen J Bax, Carina Blomström-Lundqvist, Hugh Calkins, Domenico Corrado, Spyridon G Deftereos, Gerhard-Paul Diller, Juan J Gomez-Doblas, Bulent Gorenek, Andrew Grace, Siew Yen Ho, Juan-Carlos Kaski, Karl-Heinz Kuck, Pier David Lambiase, Frederic Sacher, Georgia Sarquella-Brugada, Piotr Suwalski, Antonio Zaza, ESC Scientific Document Group, 2019 ESC Guidelines for the management of patients with supraventricular tachycardia The Task Force for the management of patients with supraventricular tachycardia of the European Society of Cardiology (ESC): Developed in collaboration with the Association for European Paediatric and Congenital Cardiology (AEPC), European Heart Journal, Volume 4I, Issue 5, I February 2020, Pages 655-720.

12. Gerhard Hindricks, Tatjana Potpara, Nikolaos Dagres, Elena Arbelo, Jeroen J Bax, Carina Blomström-Lundqvist, Giuseppe Boriani, Manuel Castella, Gheorghe-Andrei Dan, Polychronis E Dilaveris, Laurent Fauchier, Gerasimos Filippatos, Jonathan M Kalman, Mark La Meir, Deirdre A Lane, Jean-Pierre Lebeau, Maddalena Lettino, Gregory $Y$ H Lip, Fausto J Pinto, G Neil Thomas, Marco Valgimigli, Isabelle C Van Gelder, Bart P Van Putte, Caroline L Watkins, ESC Scientific Document Group, 2020 ESC Guidelines for the diagnosis and management of atrial fibrillation developed in collaboration with the European Association of Cardio-Thoracic Surgery (EACTS): The Task Force for the diagnosis and management of atrial fibrillation of the European Society of Cardiology (ESC) Developed with the special contribution of the European Heart Rhythm Association (EHRA) of the ESC, European Heart Journal, ehaa6/2, https://doi.org/10.1093/ eurheartj/ehaa6 12 . 